\title{
PENGARUH PENAMBAHAN GRAFIT TERHADAP KEKERASAN BANTALAN PERUNGGU
}

\author{
Sri Endah Susilowati \\ FT - Universitas 17 Agustus 1945 Jakarta \\ E-mail : sriendah.susilowati@yahoo.com
}

\begin{abstract}
:
Bearing with copper material are needed due to its wear resistance and strength are relatively better compared to other basic materials. One of the manufacturing process is through a powder metallurgy process. The advantages of powder metallurgy method is able to do control the number of pores and good dimensional control. In this research, the manufacture of bronze bearing material $\mathrm{Cu}-\mathrm{Sn}-\mathrm{Zn}-\mathrm{C}$ graphite (bronze bearing) by the method of powder metallurgy start of stage characterization of powders, mixing powders, compacting, until sintering (heating). The specific objective of this research was to observe the effect of the addition of variable weight fraction of graphite to the density and hardness of bearing material. The result showed with increasing weight fraction of graphite rang ing from $0 \%, 0.5 \%, 1 \%$ density and hardness increase. While the increase in weigh fraction of graphite above $1 \%$, which is $1.5 \%$ and $2.5 \%$ density and hardness decreased. This relates to the role of graphite as an amplifier and lubricants, which are well wetted by Sn and Zn, so that in addition weight fraction of graphite up to $1 \%$ density and hardness will increase. In addition graphite weight fraction above 1\%, Sn and Zn levels are still not able to wet $\mathrm{Cu}$ and Graphite perfectly so that its density and hardness will decrease. In addition graphite weight fraction of $1 \%$, density and hardness achieve optimal value, respectively amounted to $6.85 \mathrm{~g} / \mathrm{cm} 3$ and $58 \mathrm{BHN}$.
\end{abstract}

Keywords: bearing, powder metalurgy, weight fraction graphite

\begin{abstract}
ABSTRAK :
Bearing dengan material tembaga banyak dibutuhkan karena sifatnya yang memiliki ketahanan aus dan kekuatan yang relatif lebih baik dibandingkan dengan bahan dasar lainnya. Salah satu proses pembuatannya adalah melalui proses metalurgi serbuk. Keunggulan dari metode metalurgi serbuk adalah dapat dilakukannya pengontrolan jumlah pori dan kontrol dimensi yang baik. Dalam penelitian ini dilakukan pembuatan material bantalan perunggu $\mathrm{Cu}-\mathrm{Sn}-\mathrm{Zn}-\mathrm{C}$ grafit (bronze bearing) dengan metode metalurgi serbuk mulai dari tahapan karakterisasi serbuk, pencampuran serbuk, kompaksi, sampai sintering (pemanasan). Tujuan khusus penelitian ini adalah untuk melihat pengaruh variabel penambahan fraksi berat grafit terhadap densitas dan kekerasan material bearing. Dari hasil penelitian diperoleh bahwa dengan meningkatnya fraksi berat grafit mulai dari $0 \%$, $0,5 \%, 1 \%$ densitas dan kekerasan semakin meningkat. Sedangkan pada peningkatan fraksi
\end{abstract}

Jurnal Kajian Teknik Mesin

Vol. 1 No. 2 
berat grafit diatas $1 \%$, yaitu $1,5 \%$ dan $2,5 \%$ densitas dan kekerasan mengalami penurunan.Hal ini berkaitan dengan peran grafit sebagai penguat dan pelumas, yang terbasahi dengan baik oleh Sn dan Zn, sehingga pada penambahan fraksi berat grafit hingga $1 \%$ densitas dan kekerasan akan meningkat. Pada penambahan fraksi berat grafit diatas $1 \%$, Sn dan Zn yang kadarnya tetap tidak mampu untuk membasahi $\mathrm{Cu}$ dan Grafit dengan sempurna sehingga densitas dan kekerasan akan menurun. Pada penambahan fraksi berat grafit $1 \%$, densitas dan kekerasan mencapai nilai optimal, berturut-turut sebesar 6,85 $\mathrm{g} / \mathrm{cm}^{3}, 58 \mathrm{BHN}$.

Kata Kunci: bearing,metalurgi serbuk, fraksi berat grafik

\section{PENDAHULUAN}

Pengembangan material komponen alat konstruksi dan perkakas khususnya bantalan diusahakan mempunyai sifat-sifat mekanik yang lebih unggul dari sebelumnya ,terutama keunggulan dalam hal penerapan pada berbagai kondisi operasional. Salah satu tujuan terpenting dalam pengembangan material adalah menentukan apakah struktur dan sifat materialnya optimum sehingga daya tahan terhadap keausan maksimum.

Dengan semakin berkembangnya teknologi manufaktur logam, maka alternatif untuk membuat suatu produk juga semakin bervariasi, salah satunya adalah dengan metalurgi serbuk. Metalurgi serbuk merupakan ilmu yang mempelajari proses pembuatan produk dari serbuk logam mulai dari tahapan karakterisasi, pencampuran serbuk, kompaksi, hingga sintering (pemanasan). Keunggulan metalurgi serbuk dibanding proses lainnya seperti pengecoran adalah kemampuannya untuk memfabrikasi komponen-komponen yang rumit dengan toleransi dimensi yang baik dengan kualitas yang tinggi, konsumsi energi yang rendah, serta penggunaan bahan baku yang efesien ${ }^{(1)}$.

Dalam penelitian ini, akan dibuat bearing komersil dengan spesifikasi antara $\mathrm{BC}_{2}$ dan $\mathrm{BC}_{3}$ untuk aplikasi material tahan aus dan tahan korosi. Bearing ini digunakan untuk membantu pergerakan komponen dengan gesekan sekecil mungkin. Bantalan luncur adalah suatu elemen mesin yang berfungsi untuk menumpu poros berbeban, sehingga putaran atau gerakan bolak-baliknya dapat berlangsung dengan halus dan aman.

Jenis bantalan (bearing) yang akan dibuat dalam penelitian ini merupakan jenis bantalan perunggu (bronze bearing) dengan menggunakan fraksi berat $88 \% \mathrm{Cu}, 9 \% \mathrm{Sn}, 3$ $\% \mathrm{Zn}$, dan variabel fraksi berat grafit : $0 \%, 0,5 \%, 1 \%, 1,5 \%$ dan 2,5\%. Bearing perunggu berpori ini berfungsi sebagai tempat penyimpan pelumas (oil reservoir) sehingga setelah bearing dimasukkan ke dalam pelumas, maka bearing tidak perlu diberikan pelumas kembali karena pelumas sudah ada di dalam pori-pori bearing tersebut.

\section{Tujuan Penelitian}

1. Untuk mengetahui proses pembuatan material bantalan perunggu $\mathrm{Cu}-\mathrm{Sn}-\mathrm{Zn}-\mathrm{C}$ grafit (bronze bearing) dengan metode metalurgi serbuk. 
2. Untuk mengetahui pengaruh fraksi berat grafit terhadap sifat mekanik seperti kekerasan dan densitas, struktur mikro bantalan perunggu $\mathrm{Cu}-\mathrm{Sn}-\mathrm{Zn}-\mathrm{C}$ grafit (bronze bearing).

3. Menarik kesimpulan dari pengaruh variabel fraksi berat grafit yang digunakan.

\section{Ruang Lingkup Penelitian}

Batasan ruang lingkup penelitian ini adalah :

1. Bahan baku penelitian meliputi : material serbuk $\mathrm{Cu}, \mathrm{Sn}, \mathrm{Zn}$ dan Grafit.

2. Proses pembuatan bantalan perunggu (bronze bearing) dengan komposisi $88 \% \mathrm{Cu}$, $9 \% \mathrm{Sn}, 3 \% \mathrm{Zn}$, dan variabel fraksi berat grafit $0 \%, 0,5 \%, 1 \%, 1,5 \%$ dan $2,5 \%$ ini dilakukan dengan metode metalurgi serbuk dengan tahapan-tahapan mulai dari karakterisasi, mixing (pengadukan serbuk), kompaksi (penekanan), hingga sintering (pemanasan).

3. Temperatur sinter yang digunakan dalam penelitian ini yaitu $850^{\circ} \mathrm{C}$ dengan waktu tahan temperatur 5 menit.

4. Pengujian yang dilakukan dalam penelitian ini meliputi uji densitas dan uji kekerasan, serta struktur mikro.

\section{LITERATUR REVIEW}

Material berbasis tembaga dapat meliputi tembaga murni, kuningan/brasses ( $\mathrm{Cu}-$ $\mathrm{Zn}$ ), perunggu/bronzes $(\mathrm{Cu}-\mathrm{Sn})$, dan perak nikel (Ag-Ni). Aplikasi dari tiap-tiap paduan berbasis tembaga itu di antaranya ${ }^{(1)}$ :

a. Tembaga murni diaplikasikan untuk material yang membutuhkan konduktivitas termal dan listrik yang tinggi serta karakteristik material yang memiliki kekuatan dan konduktor yang baik.

b. Perunggu atau bronze yang dibuat dari campuran serbuk tembaga dan timah biasa digunakan untuk aplikasi material metalurgi serbuk nonferrous ${ }^{(1)}$. Aplikasinya digunakan untuk self-lubricating bearings karena perunggu memiliki ketahanan korosi dan ketahanan aus yang baik ${ }^{(2)}$.

c. Kuningan atau brass yang dibuat dari campuran serbuk tembaga dengan kandungan 70-90\% dan serbuk seng dengan kandungan 10-30\% biasa diaplikasikan untuk material yang membutuhkan ketahanan korosi yang tinggi, machinability yang baik, dan keuletan yang baik pula.

d. Serbuk perak nikel merupakan paduan dari tembaga, nikel, dan jenis seng yang mengandung 16-19\% nikel. Sifat mekaniknya hampir sama dengan kuningan, tetapi ketahanan korosinya jauh lebih baik dibanding kuningan. .

Seng digunakan sebagai komponen dalam pembuatan kuningan (brass) dan anoda karbon. Penambahan seng dapat melindungi komponen utama dari oksidasi. Semua paduan seng memiliki sifat machining yang baik, hasil permukaan akhir yang bagus, dan memiliki keausan tool yang rendah. Sebagai contoh, paduan seng jenis ZA-27 (Zinc-Aluminum) memiliki keuletan dan kekuatan impak yang baik. Paduan ZA-27 ini sangat cocok untuk 
aplikasi bearing dan material yang membutuhkan ketahanan aus yang tinggi. Metode pembuatan serbuk Zn dapat dilakukan dengan cara pemurnian, atomisasi, dan elektrolisa ${ }^{(4)}$.

Pertimbangan dalam pemilihan paduan bearing adalah materialnya harus memiliki koefisien gesek yang rendah. Timah memiliki koefesien gesek yang rendah sehingga memenuhi persyaratan material bearing. Namun timah secara struktural merupakan logam yang lemah (kekuatan rendah). Oleh karena itu dalam pembuatan bearing, timah dipadukan oleh tembaga dan antimoni untuk meningkatkan kekerasan, kuat tarik, dan ketahanan fatik. Dalam pembuatan perunggu berporos $(90 \mathrm{Cu}-10 \mathrm{Sn})$, timah berfungsi sebagai wetting agent yaitu untuk membasahi tembaga, dan meninggalkan pori ${ }^{(5)}$. Serbuk Sn ini dapat dibuat dengan cara penembakan, pembutiran, atomisasi, dan presipitasi kimia ${ }^{(4)}$.

Grafit yang ditambahkan dalam proses pembuatan bearing berfungsi sebagai pelumasan dan penguatan. Untuk bearing perunggu, komposisi materialnya memiliki $90 \mathrm{Cu}-10 \mathrm{Sn}$ dengan penambahan grafit sampai $1,5 \%$. Penambahan grafit digunakan untuk memodifikasi gesekan saat aplikasi. Selain itu penambahan grafit pada paduan tembagatimah juga digunakan untuk mengontrol perubahan dimensi. Grafit juga berfungsi sebagai penguat (Reinforcement) pada matriks.

Bantalan perunggu (90Cu-10Sn) memiliki ketahanan aus dan korosi yang baik, keuletan yang cukup, dan ketahanan pembebanan yang baik. Material ini memiliki poripori kecil yang saling berhubungan dengan nilai pori antara 25-35\% dari volume total Untuk aplikasi tertentu seperti alat-alat mesin, otomotif, pesawat terbang, dan konstruksi memiliki pori $10-35 \%$ dari volume total ${ }^{(4)}$

Fungsi bearing adalah untuk membantu proses pergerakan komponen dengan gesekan sekecil mungkin. Sintered self-lubricating bearing memiliki pori-pori yang berfungsi sebagai tempat penyimpanan pelumas (oil reservoir). Gambar 1 merupakan skematik bearing berpori yang berfungsi sebagai pelumas. Jika shaft mulai berputar maka gesekan logam ke logam antara shaft dengan bearing menyebabkan temperatur bearing meningkat. Akibatnya, pelumas yang ada di dalam pori bearing akan membesar dan oil wedge (ruang antara shaft dengan bearing) akan terisi sebagian oleh pelumas ${ }^{(2)}$.

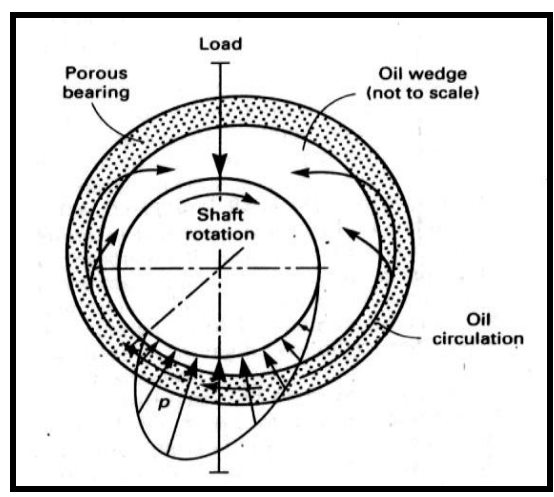

Gambar 1. Skematik Beban dan Sirkulasi Pelumas Dalam Bearing Berpori ${ }^{\text {(2) }}$ 
Aplikasi bantalan (bearing) dipergunakan untuk dudukan antara benda berputar/ poros dengan bagian yang diam. Bantalan dipergunakan untuk berbagai keperluan seperti terlihat pada tabel 1 .

Diantara beberapa teknologi pengerjaan logam, metalurgi serbuk merupakan salah satu pengerjaan logam dengan teknologi manufaktur yang berbeda. Keunggulan metalurgi serbuk dibanding proses lainnya seperti pengecoran (casting) adalah kemampuannya untuk memfabrikasi komponen-komponen yang rumit dengan toleransi dimensi yang baik dan kualitas yang tinggi, konsumsi energi yang rendah, serta penggunaan bahan baku yang efesien. Selain itu dengan metalurgi serbuk maka dapat dihindari segregasi dan machining yang biasa terjadi masalah dalam casting ${ }^{(5)}$.

Tabel 1. Aplikasi Bantalan (Bearing) ${ }^{(2)}$

\begin{tabular}{|l|l|}
\hline \multicolumn{1}{|c|}{ Jenis } & \multicolumn{1}{|c|}{ Aplikasi } \\
\hline Komponen otomotif & $\begin{array}{l}\text { Starter, generator, pompa air dan minyak, } \\
\text { pemanas, air conditioner. }\end{array}$ \\
\hline Perlengkapan rumah & $\begin{array}{l}\text { Pencuci piring, pengering baju, mesin jahit, } \\
\text { vacum cleaner, lemari es, pencampur makanan }\end{array}$ \\
\hline Peralatan pertanian & $\begin{array}{l}\text { Traktor, pemotong tali, gergaji, mesin potong } \\
\text { rumput, mesin pemetik kapas. }\end{array}$ \\
\hline Elektronik & Tape recorder, record changer \\
\hline Mesin & Mesin tik, komputer, fotokopi \\
\hline Perlengkapan industri & Mesin tekstil, mesin pengepakan, kipas listrik \\
\hline Alat-alat portable & Bor, gergaji \\
\hline
\end{tabular}

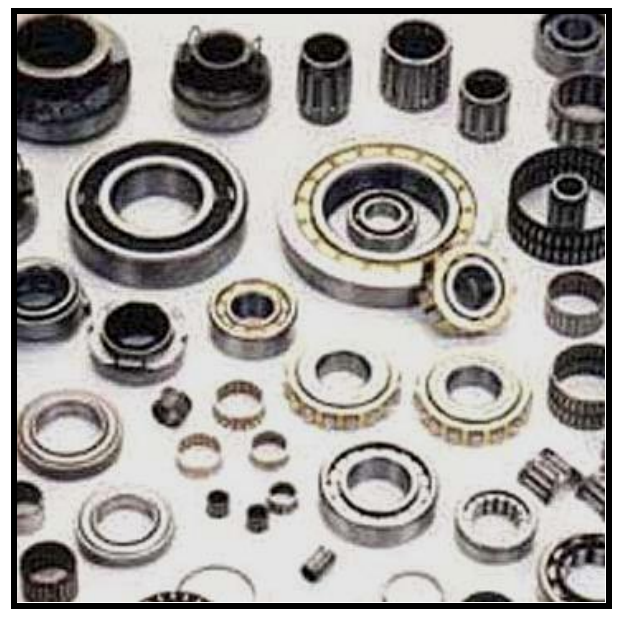

Gambar 2. Produk Bantalan (Bearing) ${ }^{(12)}$ 
Metalurgi serbuk merupakan ilmu yang mempelajari proses pembuatan produk dari serbuk logam melalui beberapa tahapan mulai dari karakterisasi (ukuran dan distribusi ukuran serbuk, bentuk serbuk, serta komposisi kimia serbuk), mixing (pencampuran serbuk), kompaksi (penekanan), hingga sintering (pemanasan). Bentuk partikel serbuk menentukan sifat massa serbuk seperti efesiensi pemadatan (packing efficiency), mampu alir (flowability), dan mampu tekan (compressibility). Bentuk partikel yang besar mempengaruhi besar kontak antar partikelnya sehingga besarnya gaya gesekan antar partikel berhubungan dengan luas permukaan partikel serbuk.

Bentuk partikel serbuk berpengaruh terhadap kontak antar partikel serbuk saat dikompaksi, yang lebih lanjut akan menentukan mekanisme perpindahan massa pada proses sinter. Dengan meningkatnya luas permukaan partikel (ukuran partikel semakin kecil, permukaan partikel semakin kasar) maka akan meningkatkan reaktivitas kimia serbuk. Hal ini akan meningkatkan penyerapan gas dan uap air dari lingkungan luar yang akan membentuk oksida-oksida pada permukaan partikel saat setelah kompaksi dan sinter $^{(7)}$.

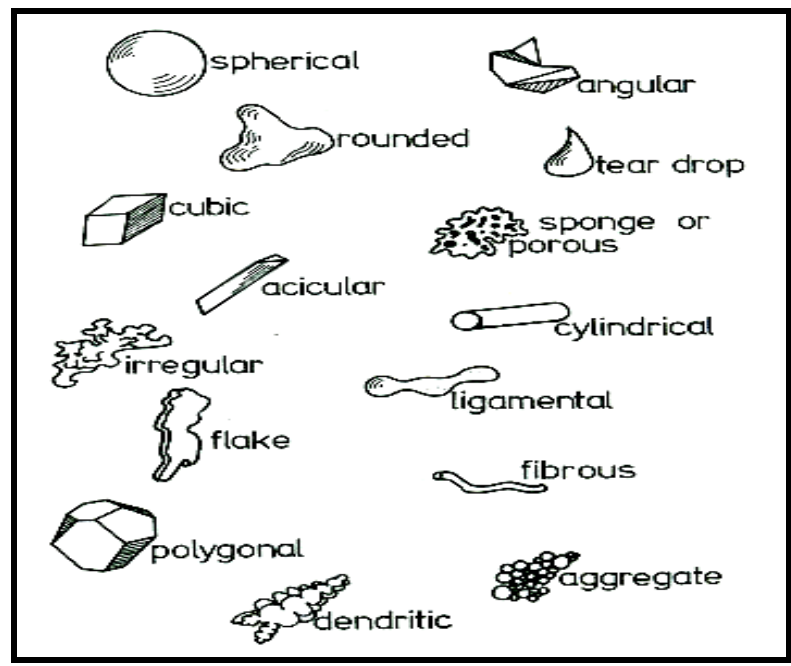

Gambar 3. Jenis-Jenis Bentuk Partikel Serbuk ${ }^{(5)}$

Kompaksi adalah suatu proses pembentukan atau pemampatan terhadap serbuk atau paduan atau campuran dari berbagai jenis serbuk sehingga mempunyai bentuk tertentu dan mempunyai kekuatan yang cukup untuk mengalami proses selanjutnya. Tekanan kompaksi yang diberikan bersumber pada tekanan eksternal untuk membentuk serbuk sehingga serbuk memiliki kepadatan yang tinggi dan pori yang rendah. Artinya tekanan yang diberikan ke serbuk, dan kecepatan tekanan merupakan parameter proses yang menentukan kepadatan serbuk ${ }^{(5)}$. Untuk bearing perunggu $90 \mathrm{Cu}-10 \mathrm{Sn}$ dan grafit $1,5 \%$, tekanan kompaksi yang digunakan yaitu antara 10-30 tsi atau 154-462 bar $^{(2)}$.

Proses sinter adalah perlakuan panas untuk mengikat partikel menjadi susunan struktur yang koheren melalui mekanisme perpindahan massa yang terjadi dalam skala 
atomik. Ikatan ini berperan dalam meningkatkan kekuatan ${ }^{(3)}$. Proses sinter dilakukan dalam dapur yang tertutup untuk mencegah pengaruh dari suasana di sekeliling dapur. Proses perpindahan massa dipengaruhi oleh temperatur sinter. Dengan meningkatnya temperatur sinter maka kecenderungan sifat mekanik bakalan yang telah disinter umumnya akan meningkat pula seperti kekerasan, densitas, kekuatan, umur fatik, kekuatan impak, ketangguhan, keuletan, dan konduktivitas listrik. Namun, peningkatan temperatur juga menimbulkan kerugian seperti penyusutan ukuran partikel (shrinkage), keakuratan dimensi berkurang, terjadinya pertumbuhan butir, biaya energi proses dan desain dapur lebih mahal.

Untuk bearing perunggu $90 \mathrm{Cu}-10 \mathrm{Sn}$ dan grafit $1,5 \%$, temperatur sinter yang digunakan yaitu antara $815-870{ }^{\circ} \mathrm{C}$ berada di bawah titik lebur matriks $\mathrm{Cu}$ yaitu $1083{ }^{\circ} \mathrm{C}^{(2)}$.

Aplikasi proses sinter serbuk campuran (mixed powder) pada serbuk tembaga dan timah yaitu untuk pembentukan perunggu berporous (porous bronze). Timah memiliki titik lebur yang lebih rendah dalam serbuk campuran ini di mana timah memiliki titik lebur $232^{\circ} \mathrm{C}$, sementara tembaga $1083^{\circ} \mathrm{C}$. Selama pemanasan timah akan melebur dan membasahi tembaga, kemudian meninggalkan pori. Karena produk akhir bearing perunggu memiliki pori maka sifat mekanik setelah sinter relatif rendah.

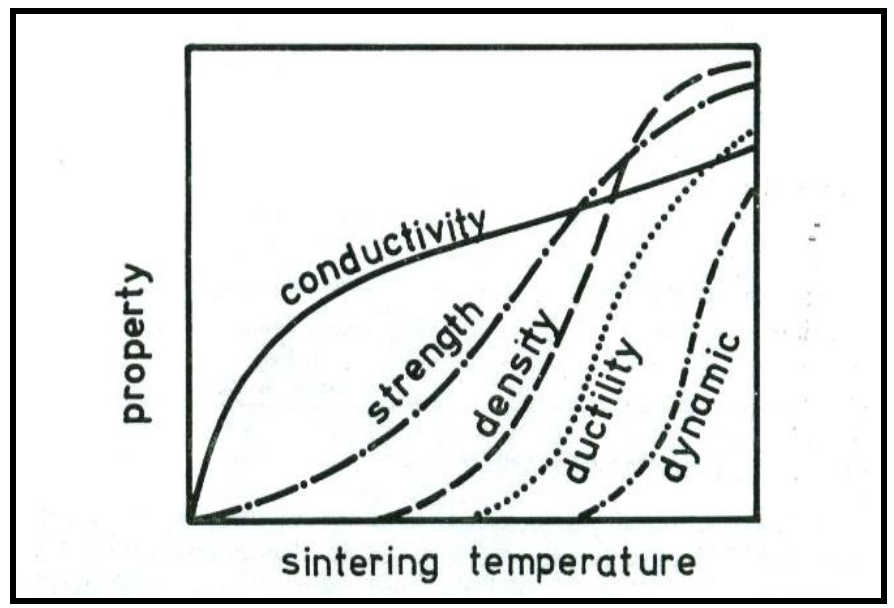

Gambar 4. Pengaruh Temperatur Sinter Terhadap Sifat Mekanik ${ }^{(\mathbf{5})}$

Gambar 5. menunjukkan perubahan ukuran dimensi terhadap kenaikan temperatur sampai $815^{\circ} \mathrm{C}$ pada campuran tembaga-timah. Perubahan dimensi yang kecil terjadi pada $232^{\circ} \mathrm{C}$ saat timah melebur, dan pembesaran (swelling) terjadi sampai mendekati $700^{\circ} \mathrm{C}$. Pembesaran (swelling) menandakan difusi yang cepat dari $\mathrm{Sn}$ ke $\mathrm{Cu}$, kemudian meninggalkan pori yang besar. Kemudian pada $700-800^{\circ} \mathrm{C}$ terjadi penyusutan ukuran, dan setelah $800^{\circ} \mathrm{C}$ terjadi swelling kembali. 


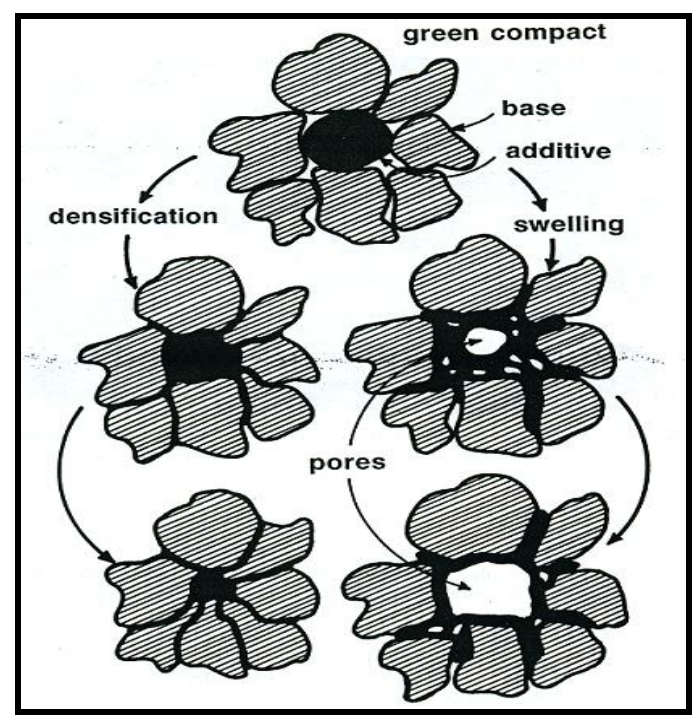

Gambar 5. Densifikasi (Pengisian Pori) dan Swelling (Pembentukan Pori) ${ }^{(\mathbf{3})}$

\section{METODOLOGI PENELITIAN}

Diagram Alir Penelitian

Karakteristik dan

Persiapan Serbuk

Pencampuran Serbuk

$88 \% \mathrm{Cu}, 9 \% \mathrm{Sn}, 3 \% \mathrm{Zn}$,

grafit $0 ; 0,5 ; 1 ; 1,5 ; 2 \%$, dan zinc stearat $0,5 \%$ selama 5 menit

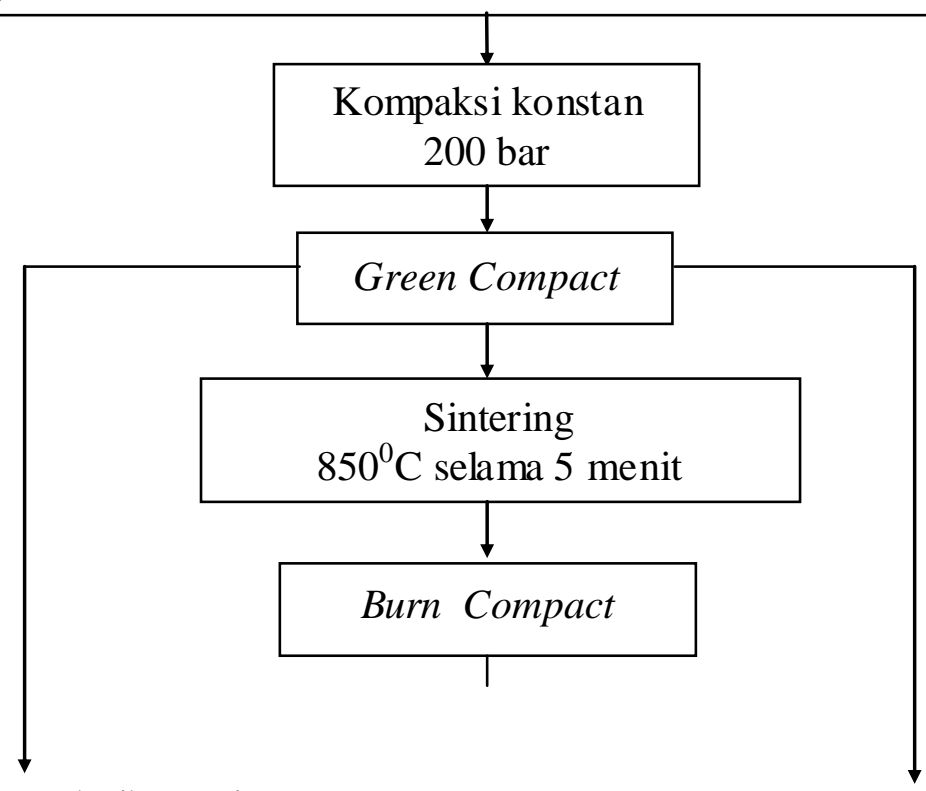

Jurnal Kajian Teknik Mesin

Vol. 1 No. 2 


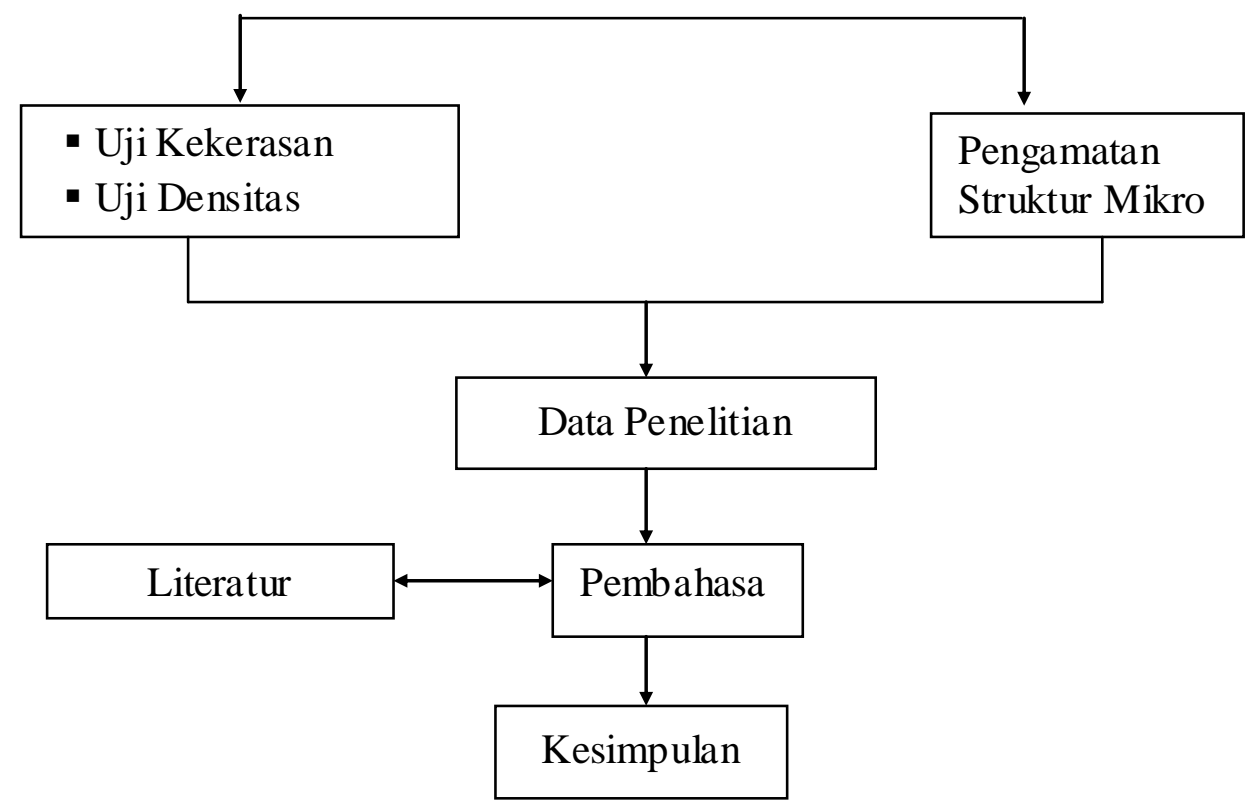

Gambar 6. Diagram Alir Proses Penelitian

\section{HASIL DAN KESIMPULAN}

\section{Karakteristik Serbuk}

\section{A. Komposisi Te mbaga}

Komposisi serbuk $\mathrm{Cu}$ yang diperoleh memiliki tingkat kemurnian 99,7 \% dan sisanya merupakan pengotor lainnya.

Distribusi Ukuran Serbuk Tembaga :

Serbuk $\mathrm{Cu}$ yang diperoleh memiliki ukuran $63 \mu \mathrm{m}$

Bentuk Serbuk Tembaga :

Dari hasil foto analisa SEM (scanning electron microscope) diketahui bahwa serbuk $\mathrm{Cu}$ memiliki bentuk dendritic.

\section{B. Komposisi Timah}

Komposisi serbuk Sn yang diperoleh memiliki tingkat kemurnian 99,935\% dan sisanya merupakan pengotor lainnya

Distribusi Ukuran Serbuk Timah :

Serbuk Sn yang diperoleh memiliki ukuran $63 \mu \mathrm{m}(97,075 \%)$ dan $125 \mu \mathrm{m}(2,61 \%)$

Bentuk Serbuk Timah : 
Dari hasil foto analisa SEM (scanning electron microscope) diketahui bahwa serbuk Sn memiliki bentuk ligamental.

\section{Komposisi Seng}

Komposisi serbuk Zn yang diperoleh memiliki tingkat kemurnian $95 \%$ dan sisanya merupakan pengotor lainnya (tabel 3.3.).

\section{Distribusi Ukuran Serbuk Seng :}

Serbuk Zn yang diperoleh memiliki ukuran $<45 \mu \mathrm{m}$.

\section{Bentuk Serbuk Seng :}

Dari hasil foto analisa SEM (scanning electron microscope) diketahui bahwa serbuk Zn memiliki bentuk spherical.

\section{Komposisi Grafit}

Komposisi serbuk C grafit yang diperoleh memiliki tingkat kemurnian 99,5\% dan sisanya merupakan pengotor lainnya

\section{Distribusi Ukuran Serbuk Grafit :}

Serbuk C grafit yang diperoleh memiliki ukuran $<50 \mu \mathrm{m}$.

\section{Bentuk Serbuk Grafit :}

Dari hasil foto analisa SEM (scanning electron microscope) diketahui bahwa serbuk $\mathrm{C}$ grafit memiliki bentuk flake.

\section{Pengujian Densitas}

Pengujian densitas dilakukan sebanyak 2 buah sampel untuk setiap fraksi berat grafit yang berbeda. Data pengujian densitas (tabel2) diperoleh dari hasil pengukuran berat sampel dalam keadaan kering, berat di dalam air, dan volume sampel.

Tabel 2. Data Pengujian Densitas Non Sinter dan Sinter

\begin{tabular}{|c|c|c|c|c|c|c|c|c|}
\hline Perlakuan & $\begin{array}{l}\text { Fraksi } \\
(\%)\end{array}$ & $\begin{array}{c}\text { Berat } \\
\text { kering }(\mathrm{mk}) \\
(\mathrm{g})\end{array}$ & $\begin{array}{l}\text { Berat } \\
\text { dlmair } \\
(\mathrm{ma})(\mathrm{g})\end{array}$ & $\begin{array}{c}\rho_{\text {air }} \\
\left(\mathrm{g} / \mathrm{mm}^{3}\right)\end{array}$ & $v(\mathrm{ml})$ & $\begin{array}{c}\rho \\
\left(\mathrm{g} / \mathrm{mm}^{3}\right)\end{array}$ & $\begin{array}{l}\text { Standar } \\
\text { Deviasi }\end{array}$ & $\begin{array}{l}\rho\left(\mathrm{g} / \mathrm{mm}^{3}\right) \\
\text { Rata-rata }\end{array}$ \\
\hline \multirow{10}{*}{ 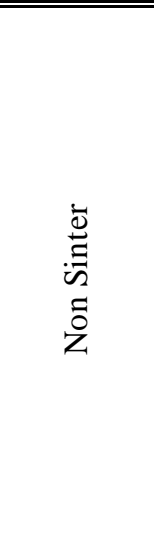 } & \multirow{2}{*}{0} & 10.35 & 1.16 & \multirow{2}{*}{0.9875} & 1.17 & 8.811 & \multirow{2}{*}{0.151} & \multirow{2}{*}{8.85} \\
\hline & & 10.36 & 1.19 & & 1.21 & 8.597 & & \\
\hline & \multirow{2}{*}{0.5} & 9.84 & 1.1 & \multirow{2}{*}{0.9875} & 1.11 & 8.834 & \multirow{2}{*}{0.044} & \multirow{2}{*}{8.80} \\
\hline & & 9.86 & 1.11 & & 1.12 & 8.772 & & \\
\hline & \multirow{2}{*}{1} & 10.42 & 1.18 & \multirow{2}{*}{0.9875} & 1.19 & 8.720 & \multirow{2}{*}{0.130} & \multirow{2}{*}{8.77} \\
\hline & & 10.46 & 1.16 & & 1.17 & 8.905 & & \\
\hline & \multirow{2}{*}{1.5} & 10.74 & 1.2 & \multirow{2}{*}{0.9875} & 1.22 & 8.838 & \multirow{2}{*}{0.114} & \multirow{2}{*}{8.70} \\
\hline & & 10.72 & 1.22 & & 1.24 & 8.677 & & \\
\hline & \multirow{2}{*}{2.5} & 10.56 & 1.23 & \multirow{2}{*}{0.9875} & 1.25 & 8.478 & \multirow{2}{*}{0.132} & \multirow{2}{*}{8.38} \\
\hline & & 10.58 & 1.26 & & 1.28 & 8.292 & & \\
\hline
\end{tabular}




\begin{tabular}{|c|c|c|c|c|c|c|c|c|}
\hline \multirow{10}{*}{ 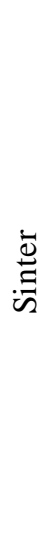 } & \multirow{2}{*}{0} & 9.63 & 1.43 & \multirow{2}{*}{0.9516} & 1.56 & 6.170 & \multirow{2}{*}{0.030} & \multirow{2}{*}{6.15} \\
\hline & & 9.63 & 1.44 & & 1.57 & 6.127 & & \\
\hline & \multirow{2}{*}{0.5} & 9.66 & 1.37 & \multirow{2}{*}{0.9516} & 1.50 & 6.461 & \multirow{2}{*}{0.033} & \multirow{2}{*}{6.44} \\
\hline & & 9.66 & 1.38 & & 1.51 & 6.414 & & \\
\hline & \multirow{2}{*}{1} & 9.65 & 1.28 & \multirow{2}{*}{0.9516} & 1.40 & 6.908 & \multirow{2}{*}{0.075} & \multirow{2}{*}{6.85} \\
\hline & & 9.65 & 1.3 & & 1.42 & 6.801 & & \\
\hline & \multirow{2}{*}{1.5} & 9.77 & 1.36 & \multirow{2}{*}{0.9516} & 1.48 & 6.582 & \multirow{2}{*}{0.034} & \multirow{2}{*}{6.56} \\
\hline & & 9.77 & 1.37 & & 1.50 & 6.534 & & \\
\hline & \multirow{2}{*}{2.5} & 9.85 & 1.66 & \multirow{2}{*}{0.9516} & 1.81 & 5.437 & \multirow{2}{*}{0.047} & \multirow{2}{*}{5.47} \\
\hline & & 9.85 & 1.64 & & 1.79 & 5.503 & & \\
\hline
\end{tabular}

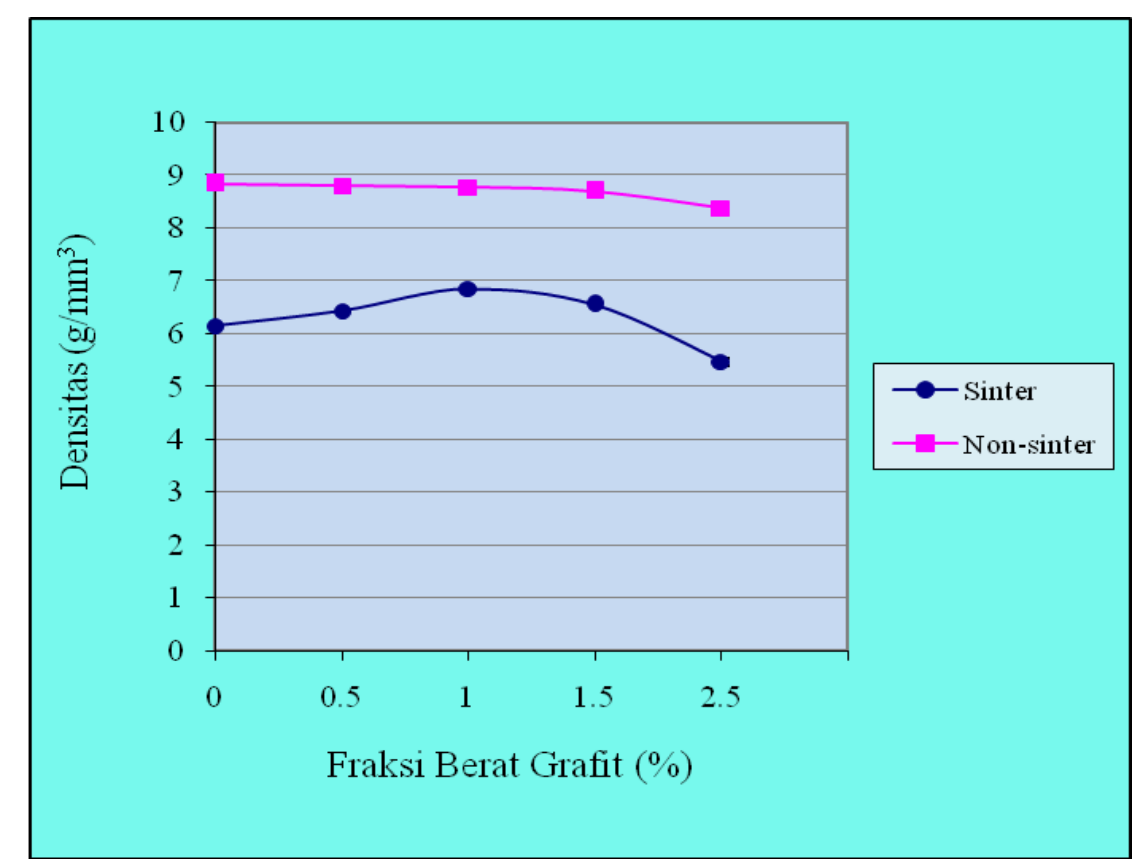

Gambar 7. Kurva Hubungan Densitas Terhadap Fraksi Berat Grafit Pada Material Bronze Bearing $\mathrm{Cu}-\mathrm{Sn}-\mathrm{Zn}+\mathrm{C}$

Dari hasil pengujian densitas diperoleh bahwa nilai densitas mengalami peningkatan seiring dengan kenaikan fraksi berat grafit dan mencapai optimal pada fraksi berat $1 \%$ dan mengalami penurunan pada fraksi berat $1,5 \%$ dan $2,5 \%$ (gambar 7 ). Nilai densitas optimal diperoleh pada fraksi berat grafit $1 \%$ sebesar $6,85 \mathrm{gr} / \mathrm{cm}^{3}$, kemudian nilai densitas mengalami penurunan hingga fraksi berat grafit 2,5\% menjadi sebesar 5,47 $\mathrm{gr} / \mathrm{cm}^{3}$. Pada material non-sinter, densitas mengalami penurunan dengan penambahan fraksi berat grafit $0 \%, 0,5 \%, 1 \%, 1,5 \%$, dan $2,5 \%$ berturut-turut $8,85 \mathrm{gr} / \mathrm{cm}^{3}, 8,80 \mathrm{gr} / \mathrm{cm}^{3}$, $8,77 \mathrm{gr} / \mathrm{cm}^{3}, 8,70 \mathrm{gr} / \mathrm{cm}^{3}$, dan $8,38 \mathrm{gr} / \mathrm{cm}^{3}$.

Pada saat sampel tanpa penambahan grafit ( fraksi berat 0\%), densitas yang diperoleh merupakan hasil dari proses sintering dimana terjadi proses densifikasi partikel akibat adanya tranpor massa. Pada proses sinter ini partikel-partikel tembaga memiliki daerah 
kontak yang akan membentuk leher. Kemudian terjadi perpindahan massa. Pada tahap ini, terjadi perpindahan massa yang menyebabkan terjadinya pertumbuhan leher antar partikel. Pada tahap ini pori-pori mulai terpisah karena titik kontak membentuk batas butir. Selain itu, pada tahap ini juga terjadi penyusutan (shrinkage), pengurangan luas permukaan, dan pemadatan (densification). Adanya pori pada sampel diakibatkan adanya penyusutan pada saat intermediate stage, dimana pori yang ada ukurannya lebih kecil dibandingkan pori pada bakalan sebelu sinter, namun jumlahnya lebih banyak. Pori yang memiliki bentuk lebih besar, diakibatkan adanya penguapan zinc stearat pada saat proses sinter, sehingga meninggalkan pori yang lebih besar dibandingkan pori akibat penyusutan.

Pada saat penambahan grafit dengan fraksi berat $0,5 \%$ dan $1 \%$ densitas sampel semakin bertambah. Penambahan densitas pada sampel diakibatkan karena pori yang timbul akibat proses sinter maupun penguapan zinc stearat dapat diisi oleh grafit. Grafit yang mengisi pori-pori pada sampel meminimalisasi ruang kosong pada sampel sehingga pada volume yang tetap berat sampel akan bertambah, sehingga densitas akan naik. Grafit mampu mengisi pori karena adanya Sn dan Zn yang berfungsi sebagai coupling agent antara $\mathrm{Cu}$ dan grafit.

Adanya $\mathrm{Sn}$ dan $\mathrm{Zn}$ menjadi sangat penting karena antara $\mathrm{Cu}$ dan grafit memiliki sifat pembasahan yang buruk, terutama $\mathrm{Cu}$ sebagai matrik tidak mengalami fasa cair. Adanya $\mathrm{Sn}$ dan $\mathrm{Zn}$ yang selama proses sintering dengan suhu $850^{\circ} \mathrm{C}$ mengalami fasa cair, memungkinkan terjadinya pembasahan antara $\mathrm{Cu}$ dan grafit. Adanya $\mathrm{Sn}$ dan $\mathrm{Zn}$ dalam fasa cair memungkinkan terjadinya pembasahan dalam tiga cara, yaitu : dengan mengurangi tegangan permukaan antara $\mathrm{Cu}$ dan grafit, (ii) dengan mengurangi energi antar-muka padat-cair, dan (iii) dengan mempromosikan reaksi kimia pada antar-muka dari padat-cair.

Namun, pada penambahan fraksi berat grafit yang lebih banyak, ternyata densitas sampel turun. Penurunan yang signifikan terjadi pada saat penambahan fraksi berat grafit sebesar 2,5\%. Penurunan yang signifikanini dapat dilihat dari slope kemiringan kurva densitas vs fraksi berat grafit (gambar 7) yang curam. Hal ini terjadi karena Sn dan Zn yang seharusnya berfungsi sebagai coupling agent, tidak mencukupi jumlahnya untuk membasahi seluruh grafit secara utuh. Partikel grafit yang memiliki bentuk flake, memiliki luas permukaan yg cukup besar, hanya sebagian saja yang akhirnya melekat pada $\mathrm{Cu}$. Bagian partikel grafit yang tidak dibasahi oleh $\mathrm{Sn}$ dan $\mathrm{Zn}$ akan menimbukan ruang kosong antara $\mathrm{Cu}$ dan partikel grafit. Hal ini akan menyebabkan penambahan jumlah pori pada sampel selain pori yang sudah ada akibat proses sinter dan penguapan zinc stearat.

Pori-pori yang timbul akibat proses sintering dan penguapan zinc stearat pada sampel akan berkurang dengan optimal akibat adanya grafit yang mengisinya hingga fraksi berat grafit $1 \%$. Dengan penambahan fraksi berat grafit lebih dari $1 \%$, yaitu sebesar $1,5 \%$ dan $2,5 \%$ akan mengakibatkan penambahan pori sehingga densitas akan menurun seiring dengan penambahan grafit.

\section{Pengujian Kekerasan}

Jurnal Kajian Teknik Mesin

Vol. 1 No. 2 
Pengujian kekerasan dilakukan dengan menggunakan metode Brinnell sebanyak 3 buah sampel untuk setiap variabel fraksi berat grafit. Setiap pengujian dilakukan pada 3 titik yang berbeda dari setiap sampel sehingga diperoleh nilai kekerasan rata-rata untuk tiap sampel. Dari hasil pengujian (tabel 3) diperoleh nilai kekerasan semakin meningkat seiring dengan kenaikan fraksi berat grafit hingga nilai optimal pada fraksi berat $1 \%$, kemudian nilai kekerasan turun pada fraksi berat grafit 1,5\% dan 2.5\% (gambar 8). Nilai kekerasan optimal diperoleh pada fraksi berat grafit $1 \%$ sebesar $58 \mathrm{BHN}$, kemudian nilai kekerasan mengalami penurunan yang signifikan pada fraksi berat grafit $2.5 \%$ menjadi sebesar 28 BHN. Pada kondisi non-sinter, penambahan fraksi berat grafit $0 \%, 0,5 \%, 1 \%, 1,5 \%$, dan 2,5\% akan menurunkan kekerasan berturut-turut 46, 43, 42, 40, dan 33 BHN.

Nilai kekerasan ini juga berhubungan dengan densitas, dimana densitas yang tinggi memiliki kekerasan yang relatif tinggi karena adanya ikatan antar partikel yang diperoleh dari proses pembasahan. Semakin tinggi densitas suatu material maka jarak antar atom menjadi semakin dekat dan kekuatan ikatan menjadi semakin kuat.

Dari data penelitian (tabel 3 dan gambar 8 ), nilai kekerasan meningkat pada penambahan fraksi berat grafit $0,5 \%$ dan maksimum $1 \%$. Sesuai dengan teori, bahwa penambahan grafit akan meningkatkan kekerasan karena grafit akan menghalangi pergerakan dislokasi. Hal ini tidak terlepas dari peran Sn dan Zn sebagai coupling agent yang menyediakan pembasahan yang optimal sehingga lapisan antar muka ini dapat mentransfer beban dengan baik dari $\mathrm{Cu}$ menuju grafit. Pernyataan ini juga didukung oleh data densitas pada variabel fraksi berat grafit tersebut meiliki hubungan berbanding lurus.

Pada penambahan fraksi berat grafit sebesar 1,5 dan 2,5\%, nilai kekerasan mengalami penurunan, terutama pada fraksi berat grafit 2,5\% dimana penurunan kekerasan signifikan. Penambahan fraksi berat grafit ini tidak diikuti dengan penambahan kadar Sn dan Zn yang berfungsi sebagai coupling agent. Hal ini menyebabkan lapisan antar-muka yang berperan sebagai media transfer beban tidak berfungsi dengan baik. Lapisan antar-muka yang lemah akan menghasilkan kekakuan dan kekuatan yang rendah. Kurangnya kadar Zn dan Sn ini juga menyebabkan bertambahnya pori-pori. Dan menurut Aghajanian dan kawan-kawan, bahwa terjadi penurunan nilai kekerasan dengan peningkatan jumlah porositas. Sehingga pada penambahan fraksi berat diatas $1 \%$ nilai kekerasan akan terus mengala mi penurunan (gambar 8).

Tabel 3. Data Pengujian Kekerasan

\begin{tabular}{|c|c|c|c|c|c|c|c|c|}
\hline \multirow[b]{2}{*}{ Sampel } & \multirow{2}{*}{\multicolumn{2}{|c|}{$\begin{array}{c}\text { Fraksi berat } \\
(\%)\end{array}$}} & \multicolumn{3}{|c|}{$\mathrm{d}$} & \multirow[b]{2}{*}{ BHN } & \multirow{2}{*}{$\begin{array}{l}\text { Standar } \\
\text { Deviasi }\end{array}$} & \multirow{2}{*}{$\begin{array}{c}\text { BHN } \\
\text { Rata- }- \\
\text { rata }\end{array}$} \\
\hline & & & $\mathrm{x}$ & $\mathrm{y}$ & Rata-rata & & & \\
\hline \multirow{2}{*}{ 艺 } & \multirow{2}{*}{0} & $\mathrm{a}$ & 1.205 & 1.205 & 1.205 & 51.43737 & \multirow{2}{*}{4.66967} & \multirow{2}{*}{46} \\
\hline & & b & 1.311 & 1.273 & 1.292 & 44.26476 & & \\
\hline
\end{tabular}

Jurnal Kajian Teknik Mesin

Vol. 1 No. 2 


\begin{tabular}{|c|c|c|c|c|c|c|c|c|}
\hline & & $\mathrm{c}$ & 1.314 & 1.314 & 1.314 & 42.67103 & & \\
\hline & & $\mathrm{a}$ & 1.315 & 1.356 & 1.3355 & 41.18824 & & \\
\hline & 0.5 & $\mathrm{~b}$ & 1.324 & 1.316 & 1.32 & 42.25001 & 0.905919 & 43 \\
\hline & & $\mathrm{c}$ & 1.302 & 1.317 & 1.3095 & 42.99056 & & \\
\hline & & $\mathrm{a}$ & 1.315 & 1.318 & 1.3165 & 42.49491 & & \\
\hline & 1 & $\mathrm{~b}$ & 1.344 & 1.345 & 1.3445 & 40.58833 & 0.990438 & 42 \\
\hline & & $\mathrm{c}$ & 1.321 & 1.326 & 1.3235 & 42.00703 & & \\
\hline & & $\mathrm{a}$ & 1.325 & 1.336 & 1.3305 & 41.52674 & & \\
\hline & 1.5 & $\mathrm{~b}$ & 1.346 & 1.381 & 1.3635 & 39.36019 & 1.395258 & 40 \\
\hline & & $\mathrm{c}$ & 1.362 & 1.379 & 1.3705 & 38.92038 & & \\
\hline & & $\mathrm{a}$ & 1.379 & 1.388 & 1.3835 & 38.12102 & & \\
\hline & 2.5 & $\mathrm{~b}$ & 1.346 & 1.352 & 1.349 & 40.29281 & 1.088165 & 33 \\
\hline & & $\mathrm{c}$ & 1.362 & 1.366 & 1.364 & 39.32855 & & \\
\hline & & $\mathrm{a}$ & 1.35 & 1.35 & 1.35 & 40.22754 & & \\
\hline & 0 & $\mathrm{~b}$ & 1.3 & 1.37 & 1.335 & 41.22192 & 0.692966 & 41 \\
\hline & & $\mathrm{c}$ & 1.34 & 1.32 & 1.33 & 41.5608 & & \\
\hline & & $\mathrm{a}$ & 1.32 & 1.32 & 1.32 & 42.25001 & & \\
\hline & 0.5 & $\mathrm{~b}$ & 1.28 & 1.32 & 1.3 & 43.67595 & 0.712984 & 43 \\
\hline & & $\mathrm{c}$ & 1.34 & 1.28 & 1.31 & 42.9549 & & \\
\hline & & $\mathrm{a}$ & 1.18 & 1.12 & 1.15 & 56.82874 & & \\
\hline$\stackrel{\bar{\Xi}}{\Xi}$ & 1 & $\mathrm{~b}$ & 1.18 & 1.1 & 1.14 & 57.89324 & 0.614587 & 58 \\
\hline & & $\mathrm{c}$ & 1.16 & 1.12 & 1.14 & 57.89324 & & \\
\hline & & $\mathrm{a}$ & 1.28 & 1.26 & 1.27 & 45.94123 & & \\
\hline & 1.5 & $\mathrm{~b}$ & 1.24 & 1.26 & 1.25 & 47.54205 & 0.924233 & 46 \\
\hline & & $\mathrm{c}$ & 1.26 & 1.28 & 1.27 & 45.94123 & & \\
\hline & & $\mathrm{a}$ & 1.62 & 1.58 & 1.6 & 27.49886 & & \\
\hline & 2.5 & $\mathrm{~b}$ & 1.6 & 1.55 & 1.575 & 28.51069 & 0.509653 & 28 \\
\hline & & $\mathrm{c}$ & 1.58 & 1.6 & 1.59 & 27.89804 & & \\
\hline
\end{tabular}

\section{Keterangan :}

d : Diameter jejak

BHN : Nilai Kekerasan Brinell

Jurnal Kajian Teknik Mesin

Vol. 1 No. 2 


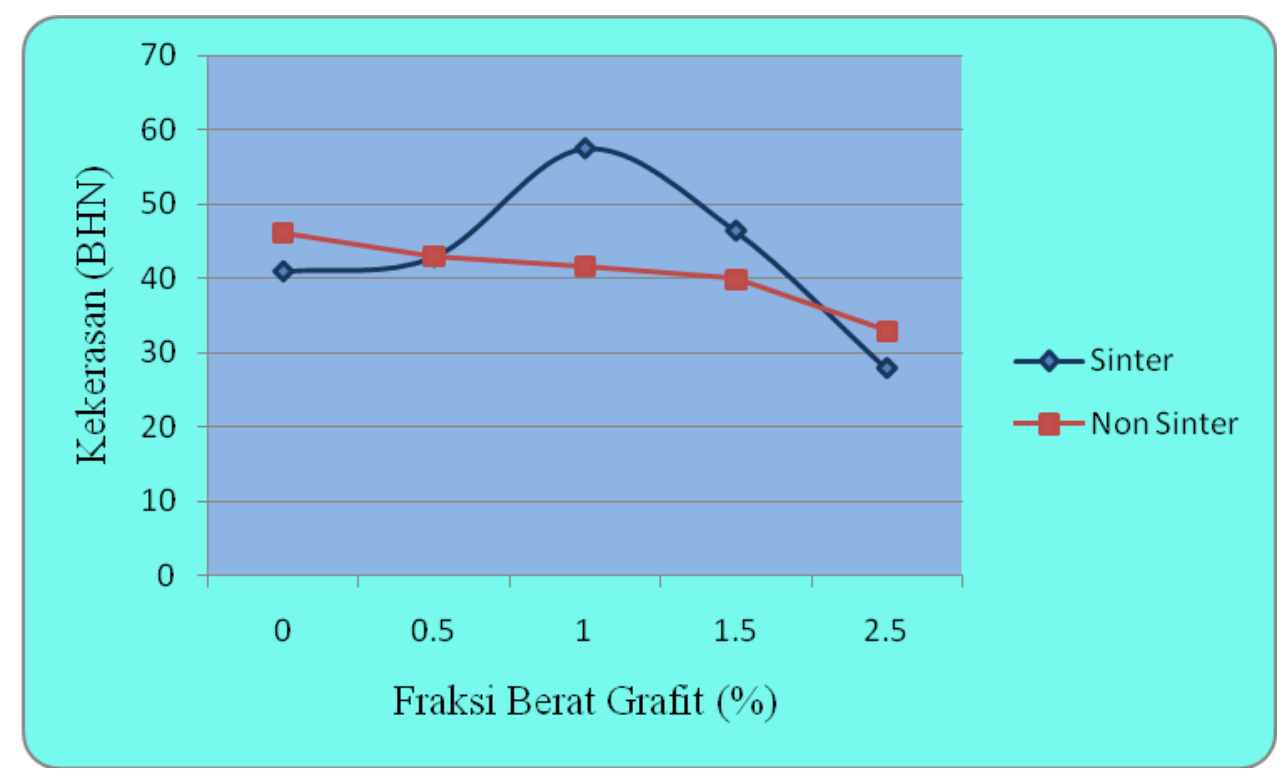

Gambar 8. Kurva hubungan kekerasan terhadap fraksi berat grafit pada material bronze bearing $\mathrm{Cu}-\mathrm{Sn}-\mathrm{Zn}+\mathrm{C}$

Pada material bronze bearing $\mathrm{Cu}-\mathrm{Sn}-\mathrm{Zn}+\mathrm{C}$ non-sinter, kekerasan lebih tinggi dibandingkan dengan material bronze bearing $\mathrm{Cu}-\mathrm{Sn}-\mathrm{Zn}+\mathrm{C}$ sinter pada penambahan fraksi berat grafit $0 \%$ dan $2,5 \%$. Penambahan fraksi berat grafit pada material bronze bearing $\mathrm{Cu}-\mathrm{Sn}-\mathrm{Zn}+\mathrm{C}$ non-sinter akan semakin menurunkan kekerasan. Penurunan nilai kekerasan ini berhubungan dengan densitas bronze bearing $\mathrm{Cu}-\mathrm{Sn}-\mathrm{Zn}+\mathrm{C}$ non-sinter. Semakin tinggi densitas maka nilai kekerasan akan semakin meningkat karena ikatan antara atom yang semakin kuat, sehingga akan diperlukan gaya yang lebih besar untuk mendeformasi material.

\section{Pengamatan Struktur Mikro}

Pengamatan struktur mikro dilakukan untuk setiap variabel fraksi berat grafit menggunakan mikroskop optik dengan pembesaran 200x. Dari hasil foto struktur mikro untuk setiap variabel fraksi berat grafit, dapat dilihat terjadi perubahan jumlah pori dan ukuran pori dari produk bantalan perunggu $\mathrm{Cu}-\mathrm{Sn}-\mathrm{Zn}-\mathrm{C}$ grafit.

Dari hasil penelitian diperoleh hasil foto struktur mikro bahwa pada fraksi berat grafit $1 \%$ (gambar 11) terjadi pengurangan pori dan distribusi pori yang merata dibandingkan dengan persentase fraksi berat yang lain. Pada fraksi berat grafit 2,5\% (gambar 13) jumlah pori meningkat signifikan dan ukurannya semakin membesar. 


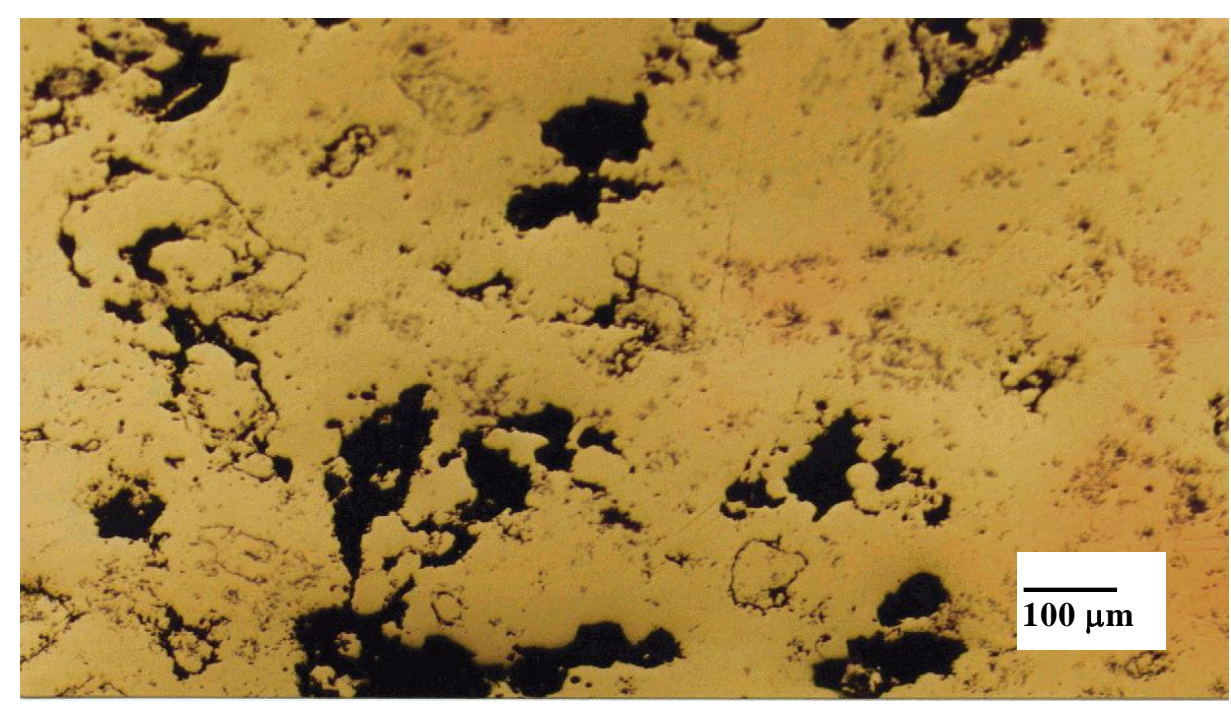

Gambar 9. Struktur Mikro material bronze bearing $\mathrm{Cu}-\mathrm{Sn}-\mathrm{Zn}+\mathrm{C}$ Sinter Dengan Penambahan Fraksi Berat Grafit 0\%

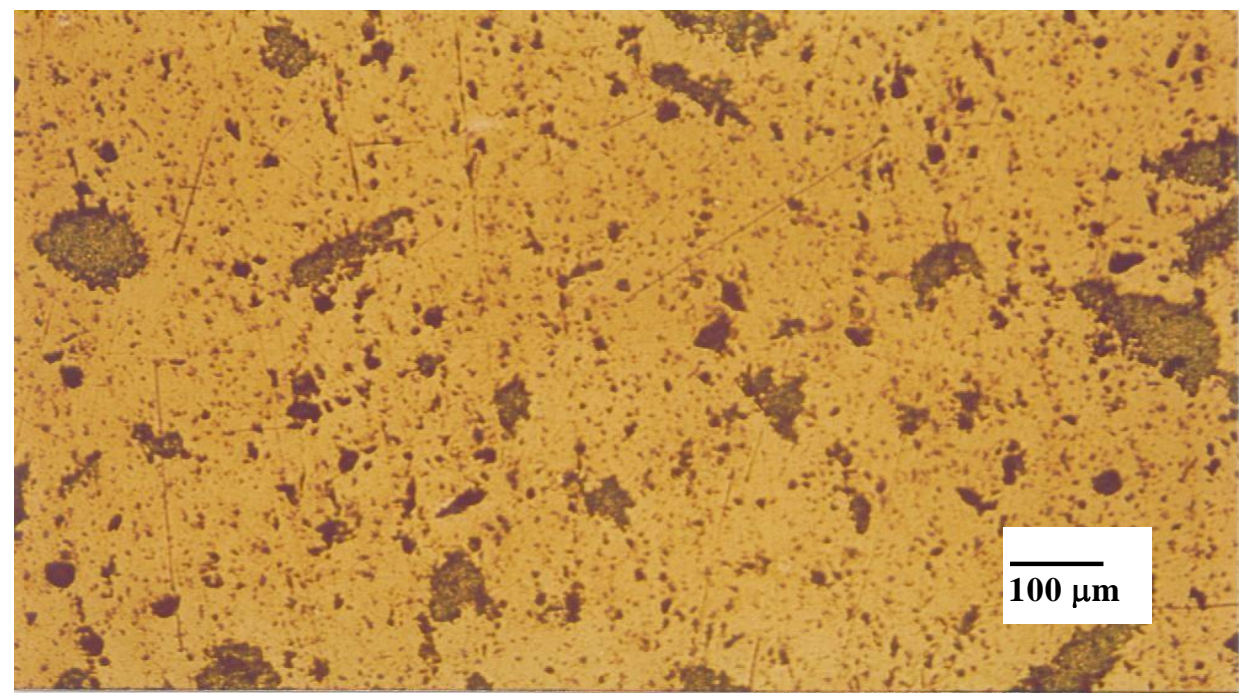

Gambar 10. Struktur Mikro material bronze bearing $\mathrm{Cu}-\mathrm{Sn}-\mathrm{Zn}+\mathrm{C}$ Non-sinter Dengan Penambahan Fraksi Berat Grafit 0\%

Jurnal Kajian Teknik Mesin

Vol. 1 No. 2 


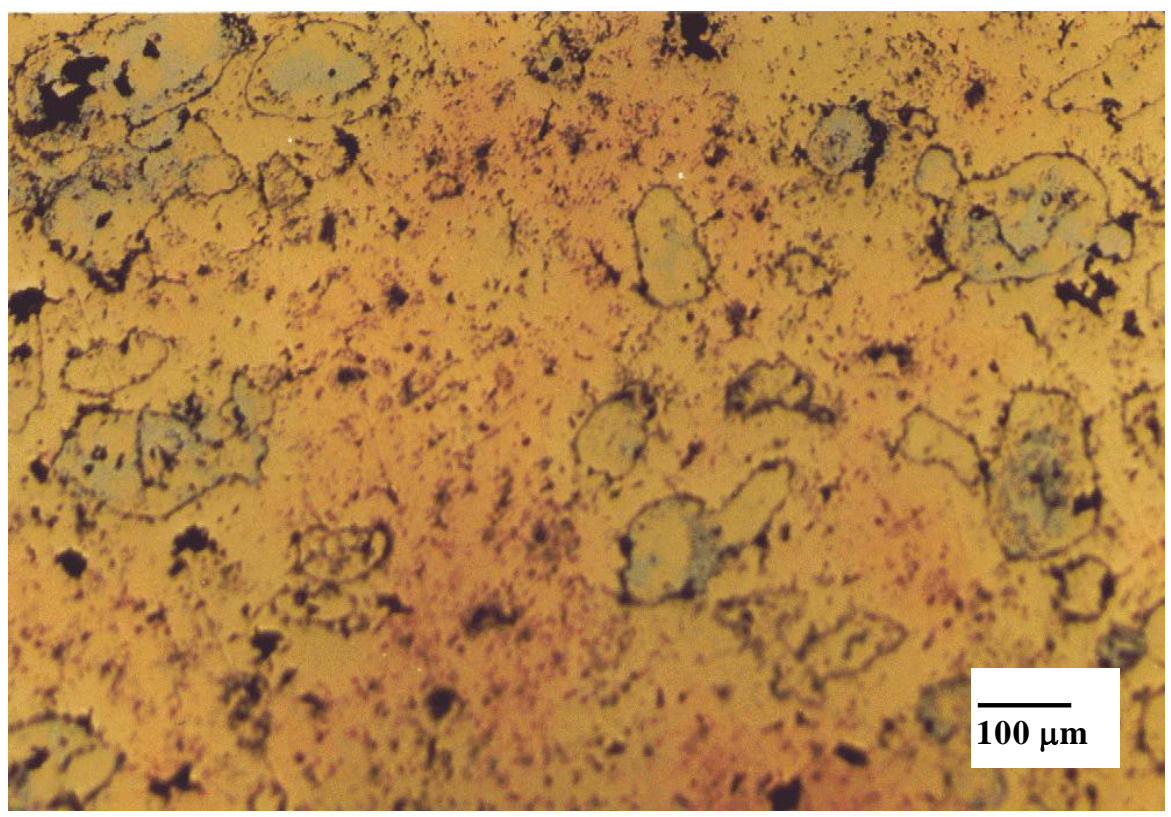

Gambar 11. Struktur Mikro material bronze bearing $\mathrm{Cu}-\mathrm{Sn}-\mathrm{Zn}+\mathrm{C}$ Sinter Dengan Penambahan Fraksi Berat Grafit 1\%

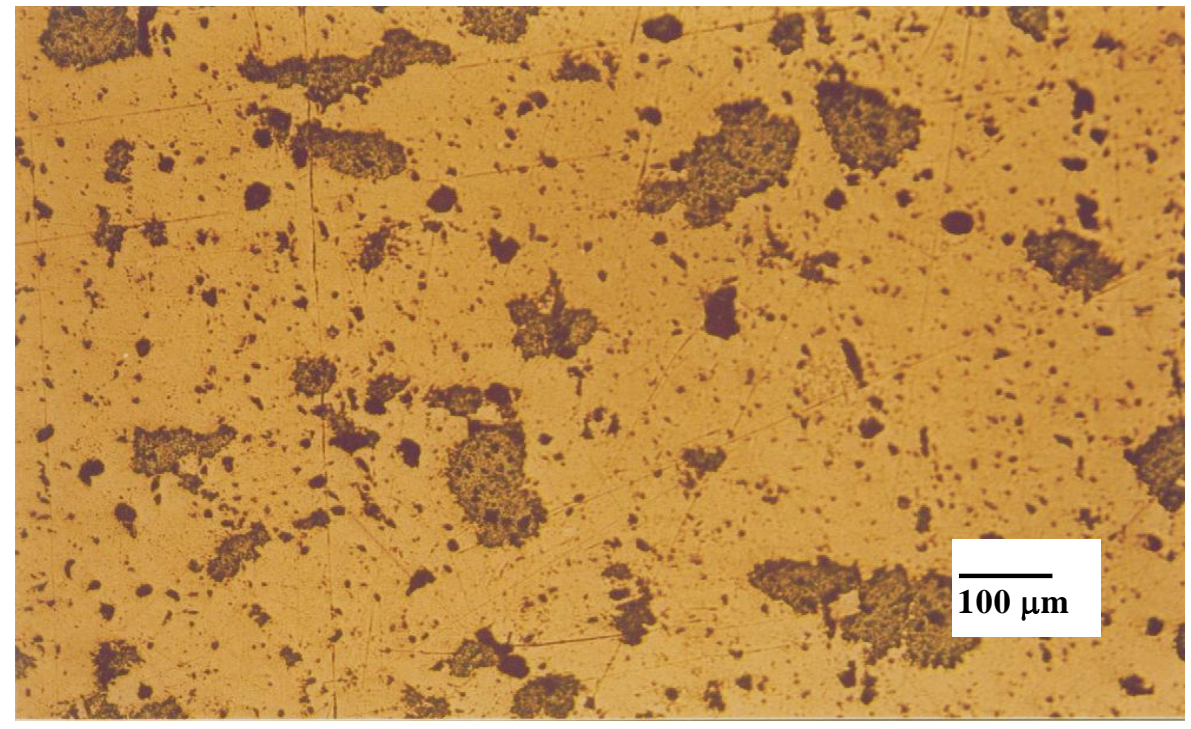

Gambar 12. Struktur Mikro material bronze bearing $\mathrm{Cu}-\mathrm{Sn}-\mathrm{Zn}+\mathrm{C}$ Non-sinter Dengan Penambahan Fraksi Berat Grafit 1\% 


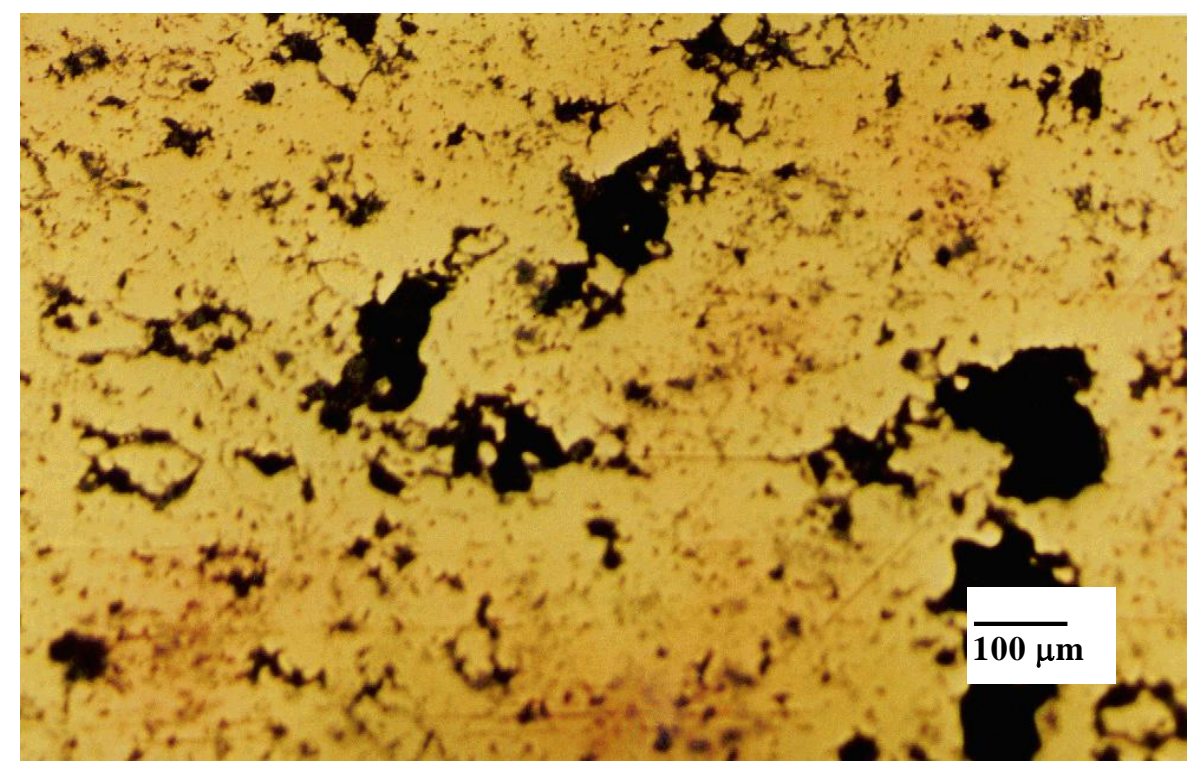

Gambar 13. Struktur Mikro material bronze bearing $\mathrm{Cu}-\mathrm{Sn}-\mathrm{Zn}+\mathrm{C}$ Sinter Dengan Penambahan Fraksi Berat Grafit 2,5\%

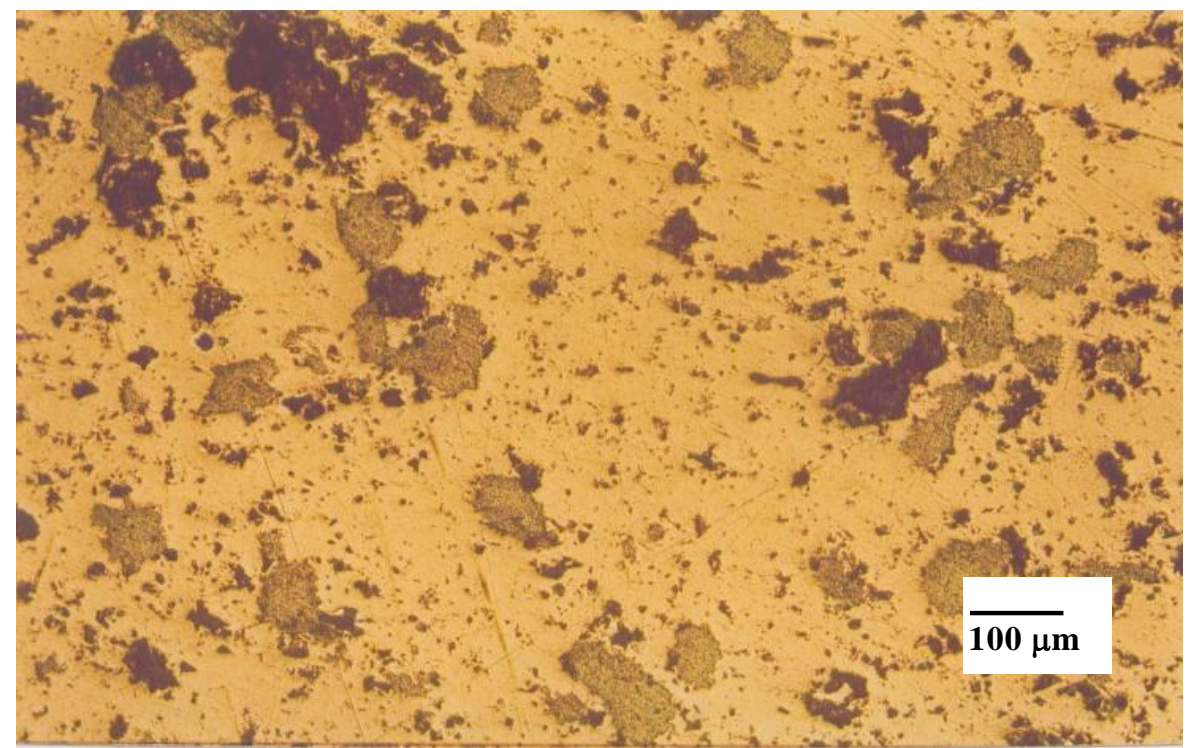

Gambar 14. Struktur Mikro material bronze bearing $\mathrm{Cu}-\mathrm{Sn}-\mathrm{Zn}+\mathrm{C}$ Non-sinter Dengan Penambahan Fraksi Berat Grafit 2,5\%

Jurnal Kajian Teknik Mesin

Vol. 1 No. 2 


\section{KESIMPULAN}

1. Proses pembuatan material bantalan perunggu (bronze bearing) $\mathrm{Cu}-\mathrm{Sn}-\mathrm{Zn}-\mathrm{C}$ grafit dapat dilakukan dengan metode metalurgi serbuk.

2. Kenaikan fraksi berat grafit sampai dengan $1 \%$ meningkatkan densitas dan kekerasan, Penambahan fraksi berat grafit diatas $1 \%$ menurunkan densitas dan kekerasan.

a. Nilai densitas mengalami kenaikan hingga titik optimum dengan nilai $6,85 \mathrm{gr} / \mathrm{cm}^{3}$.

b. Nilai kekerasan mengalami kenaikan hingga titik optimum dengan nilai $58 \mathrm{BHN}$.

c. Untuk foto struktur mikro, ukuran pori semakin mengecil dengan kenaikan fraksi berat grafit hingga $1 \%$. ukuran pori kembali membesar dan bertambah banyak pada penambahan fraksi berat grafit diatas $1 \%$.

\section{DAFTAR PUSTAKA}

1. Metal Powder Industries Federation. Powder Metallurgy Design Manual $2^{\text {nd }}$ Edition. Priceton USA. 1995. (Hal 74- 76)

2. ASM Handbook Volume 2. Properties and Selection : Nonferrous Alloy and SpecialPurpose Materials. US A : ASM International. 1990. (Hal 392-530).

3. German, Randall. M. Sintering Theory and Practice. New York : John Willey \& Sons, Inc. 1996. (Hal 8-534)

4. Goetzel. Claus G. Treatise On Powder Metallurgy Volume I-a. Technology of Metal Powders and Their Products. (Hal 198, 199)

5. German, R.M. Powder Metallurgy Science. United States of America. 1984. Hal (2-192)

6. me.emu.edu.tr/majid/ME 364/ME364_PM_process.PDF

7. Klar, Erhard. Powder Metallurgy, Apllications, Advantages, and Limitations. Ohio : American Society for Metals. 1983. (Hal 9-33)

8. Chandrawan, David dan Myrna Ariati. Metalurgi Serbuk, Teori dan Aplikasi Jilid 1. Depok. 1999. (Hal 5-67)

9. Kharisa Perdhana, Rickfy. Skripsi Pengaruh Temperatur Sinter Terhadap Kekerasan, Kekuatan Tekan, Densitas/Porositas, dan struktur Mikro Material Komposit ALSiC Produk Metalurgi Serbuk. Depok. 2002. (Hal 10-15)

10. Wirahadisaputra, Natalia. Studi Perbandingan Kondisi Kompaksi Temperatur Hangat dan Temperatur Ruang Terhadap Karakteristik Produk Metalurgi Serbuk Besi + 0,5\% Grafit. Depok. 1997. (Hal 4)

11. Lenel. Fritz V. Powder Metallurgy, Principles and Applications. Princeton, New Jersey. 1980. (Hal 193)

12. http://gengxin.en.alibaba.com/product/10163065/50048122/Deep_Groove_Ball_Bearing /Deep_Groove_Ball_Bearing/showimg.html

13. ASM Handbook Volume 2. Powder Metal Technologies and Applications. USA : ASM International. (Hal 863, 1054)

14. www.sdp-si.com/herb/spk/sdp-si/D200/PDF/D200_T16.pdf 